\title{
'Where is Katherine?' Longing and (Un)belonging in the Works of Katherine Mansfield
}

\author{
Janet Wilson
}

\section{Mansfield, 'Home' and Longing}

Recent revisions and reassessments of English literary modernism have focused on its metropolitanism, and its aesthetics of fragmentation, abstraction and artfulness. ${ }^{1}$ Remappings which aim to situate modernism more fully within its socio-cultural matrix, reconsider its transnationalism, such as the transformative cultural impact which occurred at the end of empire, due to the migration of colonial writers, many from non-elite communities, after the 1950s. ${ }^{2}$ This approach opens up new perspectives on the contribution to modernist movements of earlier colonial writers who were neither English nor American. Katherine Mansfield is traditionally celebrated as a modernist because of her formal experimentation, as well as her links with perceived avant garde writers and artists such as John Middleton Murry, A. R. Orage, J. D. Fergusson and others. In addition, the geographical complexity of modernist journals including the New Age and Rhythm, complicates the metropolitan framings of modernism. That she might be a more liminal writer, a 'colonial modernist' whose aesthetic and artistic orientations were shaped by her New Zealand origins, a view which hitherto has been little acknowledged, has recently begun to receive critical attention. ${ }^{3}$ Mansfield's colonial identity was both formative of her metropolitan modernism and marks her out as distinctive, in particular through her obsession with 'home', and with what Emma Neale describes as 'the fantasy 
of emotional settlement' ${ }^{4}$ which inspired her great New Zealand stories like 'The Garden Party', 'At the Bay' and 'Prelude'.

The title of this paper alludes to the New Zealand writer Robin Hyde's ubi sunt lament about her famous predecessor, written soon after her death: 'Where is Katherine with weeds on her grave at Fontainebleau, when what she really wanted was the dark berry along our creeks? ${ }^{5}$ While Hyde's lament concludes with a hoped-for Arthurianlike 'return', this article reflects on Mansfield's problematics of location, her ambivalence about home and her ontological state of 'unbelonging'. It argues that her colonial modernism entailed a reconfiguring of the dialectic of home and away, of belonging yet not belonging, because memory and longing led her to construct new images of locatedness in which degrees of belonging (or not) are accounted for. ${ }^{6}$ This is evident not only in her last stories about New Zealand, written as forms of commemoration and memorial, but also in her earlier 'colonial' stories in which the white settler's deracination, sometimes manifested in terms of the uncanny, demonstrates an uneasy occupation of colonial territory.

For Mansfield, who often reacted to life's experiences in extreme terms, her mixed feelings about colonial New Zealand are central to her self-positioning in metropolitan Europe, beginning with the passionate desire to escape the home in Wellington to which she had returned after nearly four years' education at Queen's College in Harley Street, London (1903-06), and to rediscover the cultural capital of England. A premonition of the conflict this will entail is found in 'Juliet', written in 1906, in which longing 'for fresh experiences, new places', carries the proviso 'but I shall miss the things that I love here' ${ }^{7}$ The effects of the loss of homeland and home, however, 
were more severe than her youthful rebellion could ever have anticipated. The tragic death of her brother, Leslie Heron Beauchamp, from a wartime training accident in October 1915, deeply traumatised her; ${ }^{8}$ in 1917 came the knowledge of her tuberculosis, making a physical return unlikely; and the fantasies in her marriage with Middleton Murry of an idealised home, were prevented from being realised by her illness. This loss and the desire for reconnection appear to have driven her to return to New Zealand through memory and imagination as her health declined. What Elizabeth Bowen calls 'the insatiable longing we call homesickness' inspired her finest stories. As Bowen says, 'her art grew not only from memory but from longing'. ${ }^{9}$

Mansfield's youthful reaction against her upbringing, family and nation, as well as her preoccupation with Oscar Wilde's celebration of the artificial in art, helped inform her selfpresentation as colonial 'arriviste' upon her arrival in England in September 1908. Fluctuations of identity, manifested in performances of herself as the exotic other - Japanese or Maori - suggest the social distance she discovered there. Similarly the experimentation with different versions of her name, the assuming of different names, and her play with masks, all suggest that impersonation, supported by her gift for mimicry, became second nature for a while. Such exhibitionism provoked the derision of some literary contemporaries, who saw her as outlandish, a wild colonial, or, in the memorable words of Virginia Woolf, like 'a civet cat that had taken to street walking'. ${ }^{10}$ Imitation and disguise may have been a form of bravado, inspired by a wish to shock and sometimes to go incognito, to adopt a form of anonymity given her relative anonymity at first in British society. The impulse very likely sprang from her infatuation with the nineteenth-century symbolists and decadents, Arthur Symons, Walter Pater, and in particular Oscar Wilde. Wilde's emphasis on craft, artifice, 
immorality and the shaping of one's own life to that of being an artist encouraged her to experience life as intensely as possible. This fin de siècle aesthetic also catalyzed her search for the unnatural within the familiar as well as the new or foreign; it included that feral savage side of her being, symptomized by her restlessness, which she explored in early vignettes in relation to the Maori and the landscape, and identified with the savage spirit of the land in her story of raw New Zealand life, 'The Woman at the Store'.

Psychologically, however, Mansfield's impersonations were a response to her innate loneliness as much as to geographical dislocation. They dramatised and reflected her positioning between cultures, the consequence of being a white settler colonial subject in a metropolitan society. But, as I shall argue, the wearing of different identities and guises also points to her ability to absorb diverse artistic influences: of Post-Impressionism, Expressionism, the Rhythmists. That her colonial identity had already undergone a metropolitan transformation during her education at Queen's College may explain Mansfield's predisposition to radical gestures such as imitation and experimentation upon relocation in a metropolitan milieu. Certainly her ability to locate the spaces between people and register the problems in crossing social distances - a feature of the late lyrical stories might be traced to this to and fro movement between cultures. Her double expatriation, first at the age of 14, when the Beauchamps travelled to England in January 1903, and then her second return to the metropolitan homeland just before she turned 20 in 1908, entailed an unusually radical bifurcation and multiplication of identity. ${ }^{11}$ As she wrote to S. S. Koteliansky in 1922, 'I am a divided being: I am always conscious of this secret disruption in me'; ${ }^{12}$ yet this internal splitting with its potential for accretions of identity seems to have 
made her adaptable, able to change roles, capable of cultural relativism and receptive to diverse experiences.

\section{Colonial versus Metropolitan Influences}

Mansfield's adolescent wish to distance herself from family and nation, then her later urge to recover belonging, are paradigmatic of subjects from the white settler colonies of New Zealand, Australia, South Africa and Canada. They can be read in terms of Homi Bhabha's argument that 'the colonial presence is always ambivalent, split between its appearance as original and authoritative and its articulation as repetition and difference'. ${ }^{13}$ Bhabha, in talking of colonial imitation (of the metropolitan coloniser), argues that the excess or slippage produced by the ambivalence of mimicry (which embodies the desire for a 'recognizable Other, as subject of difference which is almost the same but not quite'), does not merely rupture colonial discourse, it becomes transformed into an uncertainty which fixes the colonial subject as a 'partial [that is, 'incomplete' and 'virtual'] presence'. ${ }^{14}$ Critic Alan Lawson, in relating Bhabha's theories to the 'Second World' of the white settler invader colony, focuses on the inherent ambivalence of the white settler subject due to his/her inbetween status, caused by two prior sources of cultural authority and authenticity: 'the originating world of Europe, $[\ldots]$ as source of the Second World's principal cultural authority; and that other First World, that of the First Nations, whose authority the settlers not only effaced and replaced but also desired'. ${ }^{15}$ The settler's interstitial location between the European imperium and the indigene is at once colonising - symbolically erasing and depriving the indigene of voice, partly assimilating him into the European self - and subject to imperializing by the centre. Lawson claims that the settler occupies "not unbounded space 
but a place of negotiation', a 'neither/nor territory' where binaries such as self/other, here/there, colonizer/ colonized are destabilized. ${ }^{16}$ Any sense of belonging becomes problematic, even as this introduces tensions into hegemonic colonial discourse. Subjectively experienced, in betweenness with 'its internalization of the self/other binary of colonialist relations', as Stephen Slemon puts it, and its reduced ability to resist any object or discursive structure positioned as purely external to the self, fragments identity into multiple selves and self-positionings; in short, the white settler manifests what Canadian writer Denis Lee calls 'alien inauthenticity'. ${ }^{17}$ These complexities underpin Mansfield's construction of her own subjectivity and of settler life in her colonial stories.

Bhabha's theory about the incompleteness and partial presence of the colonial, Lawson's about the white settler's effacement and appropriation of indigenous authority and authenticity, and Slemon's about the settler's 'ambivalence of emplacement' between the 'First World/Third World, colonizer/colonized binary', ${ }^{18}$ help contextualize Mansfield's propensity for impersonation and statements about her own plural subjectivity -- 'True to oneself! Which self? Which of my many $[\ldots]$ hundreds of selves' - and her desire for 'our own particular self', the intimation of 'a mysterious belief in a self which is continuous and permanent'. ${ }^{19}$ Crucially moulded by the disjunctures between the imperial and the colonial worlds, and the permanent dislocation caused by being between both but not fully belonging to either, Mansfield, even before she first left New Zealand in 1903, laid claim to the dual sources of the settler's authority and authenticity. On the one hand, she befriended the Trowells, the musical English family whose twin sons she fell in love with, becoming pregnant to one of them, Garnet Trowell, after her return to London in 1908. On the other, she was erotically attracted to her half-Maori schoolfriend, Martha Grace Mahupuku (called 
'Maata'), from Miss Swainson's private school in Thorndon, writing of her in 1907: 'I want Maata. I want her as I have had her - terribly. This is unclean I know but true. What an extraordinary thing - I feel savagely crude, and almost powerfully enamoured of the child'.$^{20}$ Through her sensations of desire and longing - as in the relationships with Maata and Garnet Trowell - Mansfield mapped out her 'exotic' 'unbelonging', making a transition between erotic ties a way of focusing her colonial identity in her move from home into exile.

Mansfield saw herself as a hybrid, a metropolitan colonial or a New Zealand European, not a 'Pakeha' New Zealander. ${ }^{21}$ This identity decision partly stemmed from her dissatisfaction with her 'vulgar' family and the primitiveness of New Zealand society. As she wrote in a letter to her sister in early 1908, 'I am ashamed of young New Zealand, but what is to be done'. ${ }^{22}$ She was attracted to the Maori as the indigenous other, though, and the diary of her three week camping trip into the Ureweras in late 1907 records encounters in terms drawn from European stereotypes of romantic impressionism and exotic indigeneity. Her intense, physical relationship with Maata Mahupuku, however, enabled her to internalize the indigenous presence, to attempt to incorporate it into her identity structures, and so distance herself further from her undesirable Pakeha-New Zealand identity. As Bridget Orr points out, 'in a settled colony with policies of racial assimilation, the other is with/in you' ${ }^{23}$ Although the Maori do not feature in her mature work as subjects in their own right, Maata is an exception. Journal entries and story fragments suggest Mansfield remained obsessed by this erotic, psychic involvement, and the interplay of their identities after their relationship ceased became subject matter for writing. A half-caste Maori called Maata is the heroine of a novel outlined in 1908, while an incomplete bildungsroman of 1910 features a heroine called Maata 
who is based on Mansfield herself and incorporates elements of the Maata Mahupuku relationship. $^{24}$

The vignette, 'Summer Idylle' (1906), in which Mansfield reproduces the awakening of sexual desire between two women - one half-Maori, the other Pakeha - as a dialectic exploration of self and other, suggests that the relationship entailed a preoccupation with identity, distance and belonging. Marina, the half-Maori, is at home in the landscape, yet the Pakeha, Hinemoa, after her rhapsodic, semi-erotic awakening, becomes aware of her as exotic, foreign. The names and ethnicities are reversed (the Maori has an Anglo-Celtic name, the New Zealander a Maori name), so destabilizing ethnic stereotypes and Eurocentric colonial norms of self and other. Yet their maritime associations further suggest they represent interrelated parts of the one person, despite remaining culturally distinct: Hinemoa (the Mansfield surrogate), invokes the Hinemoa of Maori legend who swam out into a lake to join her lover on an island, because of adult prohibitions on their meeting, while the more sexually experienced Marina has a name which represents European classical nomenclature and legend.

The episode concerns the sexual arousal of the virginal Hinemoa, whom Marina calls 'Snow Maiden', as symbolised by their dive into the sea's depths and swim to an island. This awakening comes with her appreciation of Marina's ethnic difference and her belonging:

Hinemoa fell back a little to see Marina. She loved to watch her complete harmony it increased her enjoyment.

'You are just where you ought to be' she said raising her voice. 'But I [am not like that]' said Hinemoa, shaking back her hair. 'I lack that congruity'. 'It is because you are so utterly the foreign element --- you see?'25 
The gendered and racial connotations of the story include the tensions between the natural and the artificial or unnatural: the 'other' is celebrated as natural; Marina's 'congruity', her indigenous 'belonging' in the Pacific setting (which the European Hinemoa lacks), recalls Mansfield's description of a Maori girl in her Urewera notebook as the 'very incarnation of evening'. ${ }^{26}$ In terms of homoerotic, bisexual desire, Marina's hints of cruelty - saying of the fern trees which ensnare warriors, 'They are cruel even as I might wish to be to thee, little Hinemoa', her savagery, 'half shut eyes, her upper lip drawn back showing her teeth', as well as her distance, are marked out. ${ }^{27}$ Being the 'foreign element' situates her as exotic, or as the other half of the divided self, as the foreign or stranger within; according to Kristeva this is the repressed side of the self that emerges to have a conscious mind. ${ }^{28}$ In the final section cultural differences map onto ethnic divisions and specific practices are now registered as unnatural. Marina eats for breakfast the Polynesian delicacy, the 'unnatural' kumera (a root vegetable with a bluish tinge when cooked); Hinemoa, now dressed in virginal white, sensuously consumes a peach, letting the juice run through her fingers, and then breaks bread, evoking Christian ritual and atonement for guilt:

... Marina laughed. 'Hinemoa eat a koumara.'

'No, I don't like them. They're blue - they're too unnatural. Give me some bread.' Marina handed her a piece, then helped herself to a koumara, which she ate delicately, looking at Hinemoa with a strange half-smile expanding over her face. 'I eat it for that reason' she said. 'I eat it because it is blue.'

'Yes.' said Hinemoa, breaking the bread in her white fingers. ${ }^{29}$

This vignette exemplifies Mansfield's preoccupation with doubles and sexual transgressiveness, and a characteristic mode of narration in which gender and sexuality are 
organizing principles. ${ }^{30}$ In its hints of the primitive, savage and exotic, the sketch is prescient of modernist appropriations of such images and discourses, as evidenced in Roger Fry's 1910 credo about Post-Impressionist art, in the savagery embraced the Rhythmists, or the barbarism of the Fauvists. ${ }^{31}$ Primitivism would become a trademark of modernist experimentation, developed in order to counteract the staleness of modernity and the mechanisation of civilisation. Mansfield's attraction to the aims and ideals of the Expressionists evident in 'Ole Underwood', written just two years after the Post-Impressionist exhibition in London, has been noted by Pamela Dunbar, while Angela Smith sees all three of Mansfield's early 'colonial' stories written in 1912-13 as 'impressive for their Fauvist vigour'. ${ }^{32}$

'Summer Idylle' shows Mansfield exploring mutually exclusive categories, the natural and the artificial, to show how the distance between them can be overcome by sexuality and the enactment of desire. The ethnic cross-over suggested by the characters' names, and the celebration of Marina as foreign suggests that sexually transgressive behaviour as a form of youthful rebellion (as implied by the Hinemoa myth) is enjoyable, even thrilling, despite the connotations of the unnatural (as symbolised by the unnatural blue of the kumera) ${ }^{33}$ Similar play with these categories occur in her 1907 vignette, 'In the Botanical Gardens' in which she describes the gardens as 'a subtle combination of the artificial and the natural' ${ }^{34}$ Kaplan draws attention to Mansfield's use of the Wildean aesthetic framework in her aim to write 'a sketch' about the Maata/Mansfield pair, in which to 'fill it with climatic disturbance' (that is, nature) is likely to clash with 'the strange longing for the artificial' ${ }^{35}$ Mansfield at this stage emulated Wilde's critical attitude toward the natural, copying into her journal his quotation from Dorian Gray: 'Being natural is a pose and the most irritating pose I know'. ${ }^{36}$ She 
projects the desired opposite vividly in 'Juliet', whose heroine's departure from her family in London and willed alienation brings about an enigmatic smile:

She could be just as she liked - they had never known her before. O, what a comfort it was to know that every minute sent The Others further away from her! I suppose I am preposterously unnatural, she thought, \& smiled. ${ }^{37}$

These early works show Mansfield interweaving images of the natural and of 'belonging' to nature, with those of the foreign, unnatural and artificial (with transgressive sexuality being a motivation and reward); and this exploration enabled her in later stories to use her European distance to recapture a more densely nuanced sense of belonging in memory and imagination.

\section{White settler (un)belonging: the 'third rate article'}

Mansfield's diary of her camping trip to the Ureweras records, in addition to her attraction to the Maori, her scepticism about the white settler subject - namely, her touring companions, the rural Pakeha they encountered, and by extension Mansfield's bourgeois 'vulgar' family in Wellington. She comments dismissively: 'I am so tired and sick of the third rate article - give

me the Maori and the [English] tourist but nothing between, ${ }^{38}$ Although this included herself, Mansfield's Eurocentric aspirations led her to ignore such interpellations and to resist incorporation into this colonial system of representation. In London, however, she saw herself as 'a stranger', as 'the little colonial', no doubt aware of the contradictions. ${ }^{39}$ Although she separated herself from the deracinated Pakeha settler subjects of her 1912-13 colonial stories, 
she increasingly reentered the same colonial space through memories of childhood, when life began to run out for her, developing what Edward Said calls 're-filiation', or in Lydia Wevers' terms, 'a new form of relationship which marks the transition from "nature" to "culture". ${ }^{40}$ In her late stories, this terrain is inhabited by the Sheridan and Burnell families in Wellington.

Mansfield's capture of the 'alien inauthenticity' of the rural settler continues the paradigms established in 'Summer Idylle' and other early sketches, even though partly informed by the modernist valuing of alienation and artifice. It appears in three stories about the colonial outback and colonial life, which were published in Rhythm: 'The Woman at the Store' (written 1911, published in 1912), 'Ole Underwood' (written 1912, published in January 1913), and 'Millie' (written 1913, published in Rhythm's successor, the Blue Review, in June 1913). A fourth, 'Old Tar', written in 1913, is more a narrative of psychic encounter and indigenization, touching on white settler guilt with its implications of injustice and the return of the repressed. ${ }^{41}$ In turning to the savagery of nature and the cruelty of life in colonial New Zealand for her subject matter, Mansfield responded to Rhythm's edict: 'Before art could be human again it must learn to be brutal'. ${ }^{42}$ The white settler's alienation and displacement are depicted in terms of murder and betrayal, delusion and madness. Colonial space, which Alan Lawson describes as 'outside discourse, a place of non-meaning, a place of chaos that threatens the coherence of the subject', she animates as a feral, hostile force in 'The Woman at the Store'. ${ }^{43}$ The approach of evening is described as 'a curious half-hour when everything appears grotesque - it frightens - as though the savage spirit of the country walked abroad and sneered at what it saw'. ${ }^{44}$ This recalls the narrator's troubled identification with primitive, primordial nature in 'In a Botanical Garden': ‘And, everywhere that strange, indefinable 
scent. As I breathe it, it seems to absorb, to become part of me - and I am old with the age of centuries, strong with the strength of savagery'. ${ }^{45}$ The savage is also associated with Mansfield's attraction to women and with feminocentric desire, as in her 'savagely crude' feelings of frustrated love for Maata, and the description in the Urewera diary of the young Maori girl as 'passionate, violent, crudely savage'. ${ }^{46}$

The various attributions that the concept of the savage came to have for Mansfield, inform her representation of the white settler subject as isolated and asocial, whose disturbed psychology and radical alienation epitomize debasement of European enlightenment values. Extreme dislocation is epitomized in the violent, inarticulate figure of Ole Underwood, who has murdered a man, and just released from prison after twenty years and subject to fits of madness, is about to murder again. The rhythms of insanity buzzing in his head are captured in the narrative voice. The female protagonists of 'Millie' and 'The Woman at the Store', victims of patriarchal, colonial structures, are reduced to primitive gestures representing severe psychological dysfunction. The woman at the store has been driven to murder her husband, it is suggested, by her extreme isolation and deprivation of any human kindness. Wevers in fact argues she has been taken over, appropriated, by the barbaric spirit of the country which the narrator perceives as wandering about at dusk. ${ }^{47}$ A similar wandering spirit appears in 'Old Tar'. The protagonist is imaged in terms of fantasy and dream and these fairy tale features are juxtaposed to the 'uncanny' revenge that is exacted: Old Tar, who has inherited land 'bought' from the Maori, tramples and gouges it while building his dream house, and is assailed by the spirits of place.

The story can be read as a critique of colonial ideology in that it dramatizes the white settler's insertion of himself into the physical and discursive space of the indigene. 
Young Tar (as he is at first), his chest straining against his Sunday clothes as he is told about his inheritance, is a symbolic reminder of the absent Maori, whom his ancestors have exploited and displaced, and of the falseness of the settler dream, shored up by religious convictions and the hubris of white heritage, which replaces indigenous ideas of ownership. Young Tar's father tells him:

'.. yer know, boy, my Pap bought this from the Maoris - he did. Ye-es! Got it off Ole Puhi for a 'suit of clothes a' a looking glass of your Granmaw's.' My stars! He had an eye! Larst thing the ole man says to me was - "James," “e says, "don’t you be muckin about with that bit of land top of Makra Hill, Don't' you sell it. “'And it on', 'e says, 'to you an' yours."' (299)

The patriarchal desire to "and it on', suggests neglect, not just of Maori rights to the land that the settlers have wrongfully seized, but also of indigenous spirituality in relation to the land. But once the house has been completed, Old Tar's premonition of a Day of Judgement is borne out. As Lawson points out the other, being only displaced not replaced, remains to confirm the boundary of the settler self's subjectivity; and like Freud's uncanny, it is always present. ${ }^{48}$ The obliterated voices and repressed subjects whose land has been appropriated reappear as haunting disturbances in nature, another version of the savage spirit of the land:

In the quiet he heard the sea beat, beat up, and then he heard the wind, very slow, snuffling round the house like a lonely dog. 'Ooh Hee! Ooh Hee!' it sounded. 'A rare, sad noise, thought Old Tar, shaking his head to it, 'Sounds as if it'd lost 
something an' couldn't find it again'. Lost for evermore', and the sad words fell into his quiet heart and started strange uneasy ripples (301).

Old Tar's disorientation and confusion is anticipated by the narrator's fears of reprisal in 'In a Botanical Garden': 'Shall I, looking intently, see vague forms lurking in the shadow staring at me malevolently, wildly, the thief of their birthright? ${ }^{49}$ The later story illustrates that white settler unbelonging is caused by ignorance, predatory greed and transported puritanism: the white settler needs the presence of the other to know himself, but with it comes the collapse of the dream of colonisation. This moral fable is reminiscent of other tales of pioneering exploration which deal with the capture of native spiritual rites associated with the land, such as James Fenimore Cooper's Leatherstocking Tales: it concludes with Old Tar's dawning recognition, painful self-questioning and petition to his silent God: “'Wot's it doing there wot's it for?' and 'Oh Lord, wot ave I done - wot 'ave I done, Lord?"' (303). Mansfield's 'postcolonial' perspective appears in the way the lost voices and repressed presences return to haunt and disempower the settler who, following the dream of settlement, has been deluded by western notions of possession.

\section{Mansfield as colonial-metroplitan modernist}

It has been customary to see Mansfield's distance from New Zealand as crucial to her literary modernism, but for her modernism to be seen as Eurocentric, being that of an alienated metropolitan modernist. ${ }^{50}$ The complexity of her colonialism, by contrast, has been argued by Emma Neale, Bridget Orr, Mark Williams, Angela Smith and Salkat Majumadar. Certainly, 
the internal ventriloquism, discontinuous narrative structures, and alienated states of being in her autobiographical fragments and stories, can be associated with the interstitial positioning of the colonial as well as with modernist practice. There is room, therefore, for further development of a critical practice in reassessments of modernism which challenges the colonial /metropolitan binary in order to reposition Mansfield more decisively as a liminal artist, a colonial-metropolitan modernist who is located outside as well as within the international establishment.

Mansfield consciously othered herself as a colonial in England. Although her fascination with Maata Mahupuku ceased after 1915, and she abandoned her plans to write the novel Maata, the relationship would have made her more than usually aware of the construction of the social outsider, the indigenous other, the in-between subject, and more deftly to register the gaps in consciousness created by the divisions of class, gender and ethnicity. Her embrace of the white settler's 'alien inauthenticity', combined with the Wildean emphasis on the artificial and unnatural became counterpoints to her social exclusion from the British establishment. As Angela Smith points out, like the Scottish artist J. D. Fergusson, this predisposed her to follow the liberating manifestos of the Post-Impressionists and Fauvists. ${ }^{51}$ Certainly, as all attempts to write fiction at greater length led only towards thinly disguised autobiography or bildungsroman, her confinement to the short story genre might be traced to her white settler identity structures. Arguably, however, in her short life there was no time to complete her rebellion against colonialism and develop a position that was sufficiently external to her origins from which to create an extended fictional narrative.

I would not wish to claim that this paradigm can be applied with equal value to all Mansfield's work, or argue that her colonial identity structures informed all her writing or 
were singularly responsible for her formal inventiveness. But I suggest that the foundation for her great stories were already there in her early vignettes and sketches, and the modernist experimentation to which she was open was just one new way in which to develop what she had already intuited from her ambivalent and multiple positionings as a white settler subject.

\section{NOTES}

${ }^{1}$ See P. Brooker et al (eds) (2010-forthcoming) 'Introduction' to The Oxford Handbook of Modernisms (Oxford: Oxford University Press), pp. 1-13; P. Brooker and A. Thacker (eds) (2009) The Oxford Critical and Cultural History of Modernist Magazines, Vol. 1, Britain and Ireland 1880-1955 (Oxford: Oxford University Press).

${ }^{2}$ J. Esty (2004) A Shrinking Island: Modernism and National Culture in England (Princeton: Princeton University Press), p. 200.

${ }^{3}$ Most recent is Salkat Majumadar (Spring 2009) 'Katherine Mansfield and the Fragility of Pakeha Boredom', Modern Fiction Studies, 55.1, pp. 119-40 (p. 121).

4 (1999) “"Why Can’t She Stay Home?” Expatriation and Back-Migration in the Work of Katherine Mansfield, Robin Hyde and Fleur Adcock', PhD thesis, University College London, p.102.

${ }^{5}$ R. Hyde (1970 [1938]) The Godwits Fly, ed. G. Rawlinson (Auckland: Auckland University Press), pp. xx-xxi. 
${ }^{6}$ Mark Williams (2000) 'Mansfield in Maoriland: biculturalism, agency and misreading', in Howard J. Booth and Nigel Rigby (ed.) Modernism and Empire, ed. (Manchester and New York: Manchester University Press), pp. 249-74 (pp. 256-7).

${ }^{7}$ M. Scott (ed.) (1997) The Katherine Mansfield Notebooks, 2 vols (Canterbury NZ: Lincoln University Press and Daphne Brasell Associates), vol. 1, p. 51. Hereafter referred to as Notebooks 1 and Notebooks 2.

${ }^{8}$ Leslie's arrival in England in February 1915 is associated with a change of direction in her art. He and Mansfield shared memories of childhood and she composed the first draft of 'The Aloe' before he died. See the essays by C. K. Stead and J. Lawrence Mitchell in this volume.

${ }^{9}$ E. Bowen, (1996 [1956-7]) ‘A Living Writer', in J. Pilditch (ed.) (1996) The Critical Response to Katherine Mansfield (Westport, CT: Greenwood Press), pp. 70-6 (p.75); (1990) Katherine Mansfield: A Study of the Short Fiction, ed. J.F. Kobler (Boston, Mass.; Twayne), p. 142..

${ }^{10}$ A. Olivier Bell and A. McNellie (eds) (1975-1985) The Diary of Virginia Woolf, 5 vols (Harmondsworth: Penguin). Vol. 1, p. 58, ( 11 Oct 1917).

${ }^{11}$ On the consequences of double expatriation in the life of the New Zealand-born poet Fleur Adcock see J. Wilson (2007), Fleur Adcock (Plymouth: British Council and Northcote House), p. 1. This fn could be deleted?

${ }^{12}$ V. O'Sullivan and M. Scott (eds) (1984-2008), The Collected Letters of Katherine Mansfield , 5 vols (Oxford: Clarendon Press). Vol. 5, p. 304. Hereafter referred to as Letters 1, Letters 2, and so on, followed by the page number. 
${ }^{13}$ Homi K. Bhabha (1994) The Location of Culture (London and New York: Routledge), p. 107.

${ }^{14}$ Ibid., p. 86.

${ }^{15}$ Alan Lawson (1995) 'Postcolonial Theory and the "Settler" Subject', in D. Brydon (ed.) Essays on Canadian Writing, 56, 20-36 (p. 29).

${ }^{16}$ Ibid.; see also S. Slemon (1997 [1990]) 'Unsettling the Empire: Resistance Theory for the Second World', in P. Mongia (ed.) Contemporary Postcolonial Theory: A Reader, (Arnold: London), pp. $72-83$ (p. 80).

${ }^{17}$ Slemon, p. 81; D. Lee (1995) 'Writing in Colonial Space' in B. Ashcroft et al (eds) The Post-Colonial Studies Reader, (London and New York: Routledge), pp. 397-401 (400).

${ }^{18}$ Bhabha, p. 86; Lawson, p. 26; Slemon, pp. 80, 79.

${ }^{19}$ Notebooks 2, p. 204.

${ }^{20}$ Notebooks 1, pp. 103-4.

${ }^{21}$ For example, the title of the article by Vincent O'Sullivan (1994) “"Finding the Pattern: Solving the Problem": Katherine Mansfield the New Zealand European', in R. Robinson (ed.) Katherine Mansfield: In From the Margin (Baton Rouge and London: Louisana State University Press), pp. 9-24 (p. 14); Pakeha is the Maori name for foreigner; that is, the European white settler.

${ }^{22}$ Letters 1, p. 44.

${ }^{23}$ Bridget Orr (December 1989) 'Reading with the taint of the pioneer: Katherine Mansfield and Settler Criticism', Landfall, 43: 4, 447-61 (453).

24 Notebooks 1, pp. 112 and 237-61. 
${ }^{25}$ Ibid., pp. 75-6. The emendation in square brackets is Scott's. The original entry reads:

'But I like not that'.

${ }^{26}$ Ibid., p. 149.

${ }^{27}$ Notebooks 1, p. 76.

${ }^{28}$ J. Kristeva (1991) Strangers to Ourselves, trans. L. S. Roudiez (London and New York: Harvester Wheatsheaf), p. 191.

29 Notebooks 1, p. 77.

${ }^{30}$ See S. J. Kaplan (1991) Katherine Mansfield and the Origins of Modernist Fiction (Ithaca: New York: Cornell University Press), p. 9.

${ }^{31}$ Angela Smith in Katherine Mansfield, pp. 36-9, suggests that stereotypes of savagery in this story anticipate Mansfield's later engagement with Fauvism.

${ }^{32}$ P. Dunbar (1997) Radical Mansfield: Double Discourse in Katherine Mansfield's Short Stories (London: MacMillan Press and New York: St Martin’s Press), pp. 53-4; Angela Smith (2000), Katherine Mansfield: A Literary Life (New York and Hampshire:

Palgrave), pp. 82-95-.

${ }^{33}$ Hinemoa may be the prototype of Hin, the sexually ambiguous character in 'The Woman at the Store', described as 'as white as a clown', a cross-over which accentuates the inauthenticity of gendered and racial identities in this story. See Dunbar, p. 47.

${ }^{34}$ Notebooks 1, p. 170.

${ }^{35}$ Kaplan, p. 55; Notebooks 1, p. 112.

${ }^{36}$ Ibid., p. 99.

${ }^{37}$ Ibid., p. 66.

${ }^{38}$ Ibid., p. 140. 
${ }^{39}$ Notebooks 2, p. 166.

40 L. Wevers, (1995) “"The Sod Under my Feet”: Katherine Mansfield', in M. Williams and M. Leggott (eds) Opening the Book: New Essays on New Zealand Writing (Auckland: Auckland University Press), pp. 31-48 (p. 38); citing E. Said (1983), The World, the Text and the Critic (Cambridge, Mass: Harvard University Press).

${ }^{41}$ It was first published in 1974, in I. A. Gordon (ed.) Katherine Mansfield: Undiscovered Country (London: Longman), pp. 299-303. All future references are to this edition.

42 J. M. Murry et al (eds) (1911) Rhythm, 1: 1, p. 36.

${ }^{43}$ Lawson, p. 24.

${ }^{44}$ K. Mansfield (1984) 'The Woman at the Store', in The Collected Stories of Katherine Mansfield (Harmondsworth: Penguin), p. 554.-

${ }^{45}$ Notebooks 1, p. 171.

${ }^{46}$ Ibid., pp. 104 and 148.

${ }^{47}$ L. Wevers (1993) 'How Kathleen Beauchamp Was Kidnapped', in R. B. Nathan (ed.) Critical Essays on Katherine Mansfield (New York: Hall \& Co.) pp. 37-47 (p. 44); see also Dunbar, p. 45 .

${ }^{48}$ Lawson, p. 28.

${ }^{49}$ Notebooks 1, p. 171.

${ }^{50}$ Orr, p. 451.

${ }^{51}$ Smith, p. 22. 